\title{
Physician-delivered smoking cessation advice: issues identified during ethnographic interviews
}

\author{
Thomas E Kottke, Dennis G Willms, Leif I Solberg, Milo L Brekke
}

\begin{abstract}
Objective-To identify the factors that physicians believe impair their ability to provide smoking cessation advice to their patients.
\end{abstract}

Design-Ethnographic interviews of physicians.

Setting-Non-academic primary care practice.

Subjects -18 of 27 physicians who had recently participated in the intervention group of a randomised clinical trial to increase the rate at which physicians give smoking cessation advice.

Main outcome measures-Factors that the interviewees reported were affecting their ability to give smoking cessation advice.

Results - The interviews generated 439 statements that we sorted into 19 categories. We judged 10 of the categories to be statements about medical practice and smoking in general, and nine of the categories to represent barriers to giving smoking cessation advice. The barriers described by the interviewees included: lack of patient interest, lack of physician perceived self-efficacy, lack of time, lack of organisational support, lack of reward to the physician, lack of peer support, lack of staff support, and lack of interest on the part of the physician. The commercial promotion of tobacco was also identified as a barrier to giving smoking cessation advice.

Mayo Clinic and

Foundation,

Rochester, Minnesota,

USA

TE Kottke

\section{Department of} Clinical Epidemiology and Biostatistics,

McMaster University,

Hamilton, Ontario,

Canada

DG Willms

Group Health

Foundation,

Minneapolis,

Minnesota, USA

LI Solberg

Brekke Associates,

Minneapolis,

Minnesota, USA

ML Brekke

Correspondence to: Thomas E Kottke, MD, Mayo Clinic and Foundation, Rochester Minnesota 55905, USA
Conclusions - As reported by physicians who had participated in a trial to provide smoking cessation advice in their own practices, the barriers to giving smoking cessation advice are more than a lack of knowledge that smoking is a health hazard and the lack of skills to help the patient stop smoking. These additional barriers may need to be addressed if physicians are to improve the rates at which they identify their patients who smoke and assist them in quitting.

(Tobacco Control 1994; 3 : 46-49)

\section{Introduction}

The discussions of smoking in a sample of the textbooks that are used by primary care physicians focus on two themes: smoking as a threat to health and the basic skills that can help the patient stop smoking. ${ }^{1-5}$ Even the specialty textbooks on preventive medicine and monographs addressed to the practicing physician tend to be limited to these two issues. ${ }^{6-8}$

In a fashion similar to the textbooks, we originally designed the Doctors Helping Smokers trial (R01 CA38361) around the hypothesis that raising physician awareness about the hazards of smoking and offering to teach them additional intervention skills would be sufficient to recruit them to attend a skillbuilding session. We also hypothesised that the skill-building session in turn would increase the rates at which the physicians gave advice and would increase the smoking cessation rates among their patients who smoked. ${ }^{9}$ The recruitment component focused on the individual physician, ${ }^{10}$ and the skill-building component centred around urging the physicians to identify all of their patients who smoked and to convince them to stop smoking. ${ }^{9}$

The intervention did not produce the intended effects. Regardless of the recruitment materials we used, we were only able to recruit 66 physicians out of a population of more than $1000^{10}$ and, even though the physicians who participated in the trial promised that they would identify all smokers among their patients and ask them to stop smoking, little more than half of these smokers reported that they had been asked to quit. ${ }^{9}$ The participating physicians acknowledged that they were frequently unable to follow through on their goal to give smoking cessation advice to every patient who smoked.

In order to understand better why our trial failed, we followed the suggestions of experts on hypothesis generation ${ }^{11}$ and action science ${ }^{12}$ and conducted ethnographic interviews ${ }^{13}$ with 18 of the physicians who had participated in the trial. These interviews led us to reformulate our hypothesis to include attention to organisational and sociological factors as necessary components of a physician intervention programme. ${ }^{14,15}$ The broader hypothesis produced a more successful outcome. ${ }^{16}$ This paper reports the methods and findings of the ethnographic interviews.

\section{Methods}

The pool of potential interviewees for this project was the 27 physicians who had participated in the intervention group of Round I of Doctors Helping Smokers. ${ }^{9}$ However, four physicians were not available during the week that the ethnographer (DGW) was in the area, and one was not scheduled for an interview 
because she lived in a very remote region. Since we only had time to interview 20 physicians and we wished to focus on private practitioners, a physician who worked at a state mental hospital and a physician who worked at the University of Minnesota were not scheduled for interviews.

The ethnographer was unable to complete two scheduled interviews. One interview was not completed because travel time between interviews had been underestimated, and one interview was not completed because the ethnographer was unable to find the doctor's office. Interviews were completed with 18 physicians, two-thirds of the original pool.

To conduct the interviews, we used a minimally structured ethnographic format. ${ }^{13,17}$ Four physicians were interviewed as pairs, and the 14 remaining physicians were interviewed as individuals. Each interview lasted up to one hour. In order to stimulate the physicians to reflect on their experiences, we asked them how they viewed their practices, how they thought medicine was changing, and what barriers they faced when trying to provide patients with smoking cessation advice and services. We tape recorded all interviews in their entirety.

After completing the interviews, we transcribed the tapes into a computer file and broke the interviews down into statements that each represented a single complete thought. We assigned a random identification number and the identification number of the physician who made the statement to each of these statements. We then printed each statement onto a $3 \times 5$ inch note card along with its randomly assigned identification number; the identification number of the physician making the statement did not appear on the card.

Two of us (TEK and LIS) independently sorted the cards into groups that we felt contained statements with similar meanings. We assigned two group identification numbers to each statement, one for the group assignment of each sorter. We cross-referenced the groups created by the two sorters to create categories of statements. We defined a "category" as three or more statements identified as a group by both sorters. To reduce the number of categories, the two sorters reviewed the categories and combined those that they thought represented an identical construct.

\section{Results}

The interviews with the 18 physicians generated 439 statements. The number of statements per physician ranged from seven to 47 . No physician made a statement implying that they did not consider smoking to be an important problem. Only one physician made a statement implying that they lacked intervention skills.

One sorter created 68 groups from the statements, and one sorter created 62 groups. The second sorter identified 25 statements that he felt did not fall into any group. Forty-four of the groups from each sorter met the criterion of a "category" as defined above. These 44 categories contained 259 statements; 180 statements did not fall into clusters that met the criterion of a category. Upon further examination, the two sorters felt that the original 44 categories could be further reduced in number to 19 categories without any loss of information.

On the basis of their content, we judged that 137 statements in 10 categories represented statements about medical practice in general, statements about why people quit smoking, and statements about giving smoking cessation advice (table 1). More than half of the physicians made statements to the effect that medical practice was changing in negative ways. While the most frequent statements about smoking were about how the physicians counselled smokers, two-thirds of the doctors made statements that appeared to express that they were confused about why people stop smoking. Other statements referred to tools that the physicians said they used to help their

Table 1 Categories of statements not identified as barriers to giving advice

\begin{tabular}{|c|c|c|}
\hline $\begin{array}{l}\text { Categories } \\
\text { (with example statements below) }\end{array}$ & $\begin{array}{l}\text { No. of statements } \\
\text { made }\end{array}$ & $\begin{array}{l}\text { No. of physicians } \\
\text { making statements }\end{array}$ \\
\hline $\begin{array}{l}\text { Ways to talk to smokers } \\
\text { "I always tell them that I used to smoke... it helps a lot" }\end{array}$ & 49 & 13 \\
\hline $\begin{array}{l}\text { Confusion about why people quit smoking } \\
\text { "we do not know how cold turkey works" }\end{array}$ & 25 & 12 \\
\hline $\begin{array}{l}\text { Negative changes in the practice of medicine } \\
\text { "there is a lot of moving around [between HMOs]" }\end{array}$ & 21 & 10 \\
\hline $\begin{array}{l}\text { Concrete tools to give help } \\
\text { "we have a sign in the office that says: "if you want to stop } \\
\text { smoking, ask us!", }\end{array}$ & 12 & 6 \\
\hline $\begin{array}{l}\text { The helpfulness of Doctors Helping Smokers } \\
\text { "DHS helped ... I am proceeding with considerably more } \\
\text { optimism now with my patients" }\end{array}$ & 9 & 9 \\
\hline $\begin{array}{l}\text { The importance of systems } \\
\text { "[I am] trying to label my charts: smoker, non-smoker, given } \\
\text { book, etc," }\end{array}$ & 6 & 4 \\
\hline $\begin{array}{l}\text { Ongoing smoking control activities } \\
\text { "we are talking about a smoke-free clinic - we are serious } \\
\text { about getting it out of here in a year" }\end{array}$ & 4 & 3 \\
\hline $\begin{array}{l}\text { Positive changes in social expectations about tobacco use } \\
\text { "the drug store took out all tobacco products recently... [it] } \\
\text { surprised us" }\end{array}$ & 4 & 3 \\
\hline $\begin{array}{l}\text { The importance of waiting until the smoker is ready, to quit } \\
\text { "you need to "hit' people when they are ready", }\end{array}$ & 4 & 3 \\
\hline $\begin{array}{l}\text { The slowness of the physician's learning process } \\
\text { "it takes about } 5 \text { years to become reasonably effective as a } \\
\text { doctor" }\end{array}$ & 3 & 2 \\
\hline
\end{tabular}


Table 2 Categories of statements referring to barriers to giving smoking cessation advice

\begin{tabular}{|c|c|c|}
\hline $\begin{array}{c}\text { Categories } \\
\text { (with example statements below) }\end{array}$ & $\begin{array}{l}\text { No. of statements } \\
\text { made }\end{array}$ & $\begin{array}{l}\text { No. of physicians } \\
\text { making statements }\end{array}$ \\
\hline $\begin{array}{l}\text { Lack of patient interest } \\
\text { "no one hears me" }\end{array}$ & 35 & 12 \\
\hline $\begin{array}{l}\text { Low perceived self-efficacy } \\
\text { "I have had some success - but the numbers are small" }\end{array}$ & 33 & 15 \\
\hline $\begin{array}{l}\text { Lack of time } \\
\text { "The pace of everyday practice is a problem..." }\end{array}$ & 18 & 12 \\
\hline $\begin{array}{l}\text { Lack of follow-up and feedback system } \\
\text { "No statistics at all on how many of my patients quit because of } \\
\text { me" }\end{array}$ & 12 & 6 \\
\hline $\begin{array}{l}\text { Lack of reward (financial or emotional) } \\
\text { "immediate rewards are rarely there" "they will not pay for it" }\end{array}$ & 9 & 6 \\
\hline $\begin{array}{l}\text { Lack of staff support } \\
\text { "staff who smoke in the office - an ongoing battle..." }\end{array}$ & 5 & 4 \\
\hline $\begin{array}{l}\text { Lack of collegial support } \\
\text { "My colleagues do not value it" }\end{array}$ & 5 & 2 \\
\hline $\begin{array}{l}\text { Commercial promotion of tobacco } \\
\text { "Newspapers get a lot of cigarette money" }\end{array}$ & 4 & 3 \\
\hline $\begin{array}{l}\text { Lack of personal interest } \\
\text { "I like to see really sick people where you get the rewards from } \\
\text { scientific type things" }\end{array}$ & 4 & 2 \\
\hline
\end{tabular}

smokers stop smoking, testimony that Doctors Helping Smokers was helpful to them, and statements about what the physicians were trying to do to help their patients stop smoking.

We judged that 125 statements referred to nine categories of barriers to giving smoking cessation advice (table 2). Two-thirds of the statements about these barriers referred to lack of patient interest in the advice, a feeling that advice is not effective, and a lack of time to give advice. Two-thirds of the physicians made statements referring to each of these categories. The remaining statements described problems with lack of follow-up and feedback, lack of reward, lack of staff and collegial support, commercial promotion of tobacco, and a lack of interest in giving smoking cessation advice. Statements in each of these categories were made by one-third of the physicians or fewer.

\section{Discussion}

In the process of programme development, the objective needs and subjective wants of the target population, the physical and social environment into which the programme is to be introduced, and the efficacy of the programme must each be assessed. The best way to collect the assessment data is dependent on the nature of the assessment task. Ethnographic methods are particularly useful when collecting data about subjective wants and social environments. While data collected in this fashion can be ambiguous and open to differences in interpretation, they are more likely than structured questionnaire data to identify previously unrecognised concerns of the subjects for whom a programme is being developed. ${ }^{18}$

In 16 interviews, the 18 physicians who participated in this study made 439 statements about medical practice and the factors that affect their ability to give smoking cessation advice. The two most frequently mentioned categories related to experienced-based and empathy-based issues. Two-thirds of the interviewees spontaneously told us that they felt that their patients were not interested in hearing a smoking cessation message, that they felt that their intervention was not effective, and that they had trouble finding time to intervene. In addition, a minority reported that they had trouble giving follow-up advice, that they were not rewarded when they advised smokers to quit, that they felt they lacked the support of their colleagues and their staff, and that they were discouraged by the commercial promotion of tobacco. Finally, a few physicians told us that they simply lacked the personal interest to intervene.

Lack of time, ${ }^{19-21}$ concern about patient acceptance, ${ }^{21-22}$ perceived lack of benefit, ${ }^{23}$ inadequate reimbursement, ${ }^{19,22,24}$ physician overestimation of performance, ${ }^{25-31}$ and lack of organised practice support ${ }^{32-36}$ have all been described previously as barriers to the delivery of preventive services. However, nearly all of these studies were conducted in academic medical clinics.

While none of the barriers that we and others have identified were addressed in the textbooks and monographs that we found in a family practice reference library, ${ }^{1-8}$ experts in technology transfer suggest that an innovation must address the needs of the target population if it is to be adopted. ${ }^{12,37-39}$ Ethnographic research helps to define those needs by elucidating the perceptual and social environment of the interviewee. In the case of health services delivery, medical sociologists and anthropologists have observed that physician behaviour is influenced as much by the organisational context of medical practice as by the scientific basis. ${ }^{40-43}$. We integrated these principles with hypotheses generated from our interview data to design Round III of Doctors Helping Smokers, a systems-based intervention that significantly increased smoking cessation advice by a group of non-volunteer, nonacademic, private practitioners. ${ }^{16}$ Addressing the organisational and sociological factors of medical practice has produced success for other health services interventions, too. ${ }^{44-48}$

While physician advice to stop smoking is both effective and cost-effective, ${ }^{49,50}$ physicians have failed to respond to these facts by increasing the rates at which they give advice to stop smoking. ${ }^{51,52}$ The data presented here suggest that there are broader issues to be 
addressed if we are to increase the extent to which practicing physicians deal with smoking among their patients.

1 Hancock EW. Coronary artery disease - epidemiology and prevention. In: Rubinstein E, Federman DD, eds.
Scientific American medicine. New York: Scientific American, 1993, 1: VIII : pp 4-5.

2 Rigotti NA. Smoking cessation techniques in a primary care practice. In: Goroll AH, May LA, Mulley AG Jr, eds. Primary care medicine. Office evaluation and management of the adult patient. Philadelphia: Lippincott, 1987 pp 243-50.

3 Rodnick JE, Gude JK. The respiratory system. In: Taylor $\mathrm{RB}$, ed. Family medicine principles and practice, 3rd edn. New York: Springer-Verlag, 1988, p 216

4 Holbrook JH. Tobacco. In: Wilson JD, Braunwald E, Isselbacher $\mathrm{KJ}$ et al. eds. Harrison's principles of internal medicine 12th edn. New York: McGraw-Hill, 1991, pp 2158-61.

5 Richards JW Jr, Blum A. Health promotion. In: Taylor $\mathrm{RB}$, ed. Family medicine principles and practice, 3rd edn. New York: Springer-Verlag, 1988, p 98

6 Fielding JE. Smoking: health effects and control. In: Last $\mathrm{JM}$, Chin J, Fielding JE et al. eds. Maxcy-Rosenau public health and preventive medicine, 12th edn. Norwalk, CT: Appleton-Century-Crofts, 1986, pp 999-1038.

7 Green LW. Prevention and health education. In: Last JM, Chin J, Fielding JE et al. eds. Maxcy-Rosenau public health and preventive medicine, 12th edn. Norwalk, CT: Appleton-Century-Crofts, 1986, pp 1089-108.

8 Clinical opportunities for smoking intervention. A guide for the busy physician. Washington, DC: US Department of Health and Human Services (NIH Publication No (PHS) 86-2178.)

9 Kottke TE, Brekke ML, Solberg LI, Hughes JR. A randomized trial to increase smoking intervention by physicians. Doctors helping smokers, round I. $\mathcal{J} A M A$ $1989 ; 261 ; 2101-6$.

10 Kottke TE, Solberg LI, Conn S, et al. A comparison of two methods to recruit physicians to deliver smoking cessation interventions. Arch Intern Med. 1990; 150: 1477-81.

11 Glaser BG, Strauss AL. The discovery of grounded theory strategies for qualitative research. New York: Aldine, 1967.

12 Argyris C, Putnam R, Smith DM. Action science. San Francisco: Jossey-Bass, 1985, p 98

13 Agar M. The professional stranger. An informal introduction to ethnography. Orlando: Academic Press, 1980, pp 90-1.

14 Solberg LI, Maxwell PL, Kottke TE, Gepner GJ, Brekke ML. A systematic primary care office-based smoking ML. A systematic primary care office-based smo
cessation program. $\mathcal{f}$ Fam Pract $1990 ; 30: 647-54$.

15 Kottke TE, Blackburn H, Brekke ML, Solberg LI. The systematic practice of preventive cardiology. Am $\mathcal{J}$ Cardiol 1987; 59: 690-4

16 Kottke TE, Solberg LI, Brekke ML, Maxwell P, Conn SA A controlled trial to help physicians increase their smoking cessation activities: doctors helping smokers, round III. F Fam Pract 1992; 34: 701-8.

17 Willms DG, Best JA, Gilbert JR et al. A systematic approach for using qualitative methods in primar prevention research. Med Anthropol Q 1990; 4: 391-407.

$18 \mathrm{Holman} \mathrm{HR}$. Qualitative inquiry in medical research. $f \mathrm{Clin}$ Epidemiol 1993; 46: 29-36.

19 Gemson DH, Elinson J. Prevention in primary care: variability in physician practice patterns in New York variability in physician practice pattern
City. Am f Prev Med 1986;2:226-34.

20 David AK, Bolt JS. A study of preventive health attitudes and behaviors in a family practice setting. $\mathcal{f}$ Fam Pract $1980 ; 11: 77-84$.

21 Henry RC, Ogle KS, Snellman LA. Preventive medicine: physicians practices, beliefs, and perceived barriers fo implementation. Fam Med 1987; 19: 110-3.

22 Resnicow KA, Schorow M, Bloom HG, Massad R Obstacles to family practitioners' use of screening tests : determinants of practice? Prev Med 1989; 18: 101-12.

23 Battista RN, Spitzer WO. Adult cancer prevention in primary care: patterns of practice in Quebec. Am $\mathcal{J}$ Public 73: $1036-9$.

24 Orlandi MA. Promoting health and preventing disease in health care settings: an analysis of barriers. Prev Med $1987 ; 16$ : 119-30
25 Woo B, Woo B, Cook F, Weisberg M, Goldman L. Screening procedures in the asymptomatic adult: comparison of physicians' recommendations, patients' desires, published guidelines, and actual practice. $\mathscr{f} A M A$ 1985; 254: 1480-4.

26 Battista RN, Williams JT, MacFarlane LA. Determinants of preventive practices in fee-for-service primary care. Am 7 Prev Med 1990; 6:6-11.

27 McPhee SJ, Richard RJ, Solkowitz SN. Performance of cancer screening in a university internal medicine practice. $\mathcal{F}$ Gen Intern Med 1986; 1: 275-81.

$28 \mathrm{McPhee}$ SJ, Bird JA, Jenkins CNH, Fordham D. Promoting cancer screening: a randomized controlled trial of three interventions. Arch Intern Med 1989; 149: 1866-72.

29 Love RR. The physician's role in cancer prevention and screening. Cancer Bull 1988; 40:380-3.

30 Lomas J. Do practice guidelines affect practice? The effect of a consensus statement on the practice of physicians. $N$ Engl $\mathcal{F}$ Med 1989; 321: 1306-11.

31 Norton PG, Dempsey LJ. Self-audit: its effect on quality of care. F Fam Pract 1985; 21 : $289-91$.

32 Pommerenke FA, Weed DL. Physician compliance: review and application to cancer detection and prevention. $A m$ Fam Phys 1990; 43: 560-8.

33 Valente CM, Sobal J, Muncie HL, et al. Health promotion : physicians' beliefs, attitudes and practices. Am $\mathcal{F}$ Prev Med 1986; 2: 82-8.

34 Wagner EH, Thompson RS. Cancer prevention and HMOs. Cancer Invest 1988; 6: 453-9.

35 Battista RN, Mickalide $\mathrm{AD}$. Integration of preventive services into primary care: a conceptual framework for implementation. In: Goldbloom RB, Lawrence RS, eds. Preventing disease: beyond the rhetoric. New York: Springer-Verlag, 1990, pp 466-73.

36 Inui TS, Belcher DW, Carter WB. Implementing preventive care in clinical practice. I. Organizational issues ventive care in clinical practice. 1. Organizational

37 Rogers EM. Diffusion of innovation, 3rd edn. New York: Free Press, 1983, p 231.

38 Goodenough WH. Cooperation in change. New York: Russell Sage Foundation, 1963, pp 376-8.

39 Tornatsky LG, Eveland JD, Boylan MG, et al. The process of technological innovation: reviewing the literature. Productivity Improvement Research Section, Division of Industrial Science and Technological Innovation, National Science Foundation, 1983. NSF 83-37, p 220.

40 Freidson E. Profession of medicine. A study of the sociology of applied knowledge. New York: Dodd, Mead \& Co, 1970 p xi.

41 Bosk C. Forgive and remember. Managing medical failure. Chicago: University of Chicago Press, 1979.

42 Clute KF. The general practitioner, a study of medical education and practice in Ontario and Nova Scotia. education and practice in Ontario and Nova

43 Price PB, Taylor CW, Richard JM Jr, Jacobson TL. Performance measures of physicians. Salt Lake City University of Utah Press, 1963.

44 Belcher DW. Implementing preventive services. Success and failure in an outpatient trial. Arch Intern Med 1990 150: $2533-41$

45 Miller NH, Thomas RJ, Superko RH, Ghandour G, Taylor CB, DeBusk RF. Lipid-lowering therapy in post-MI patients: efficacy of a nurse-managed program. Circulation 1991; 84 (suppl II): II-328.

46 Tuomilehto J, Nissinen A, Salonen J, Kottke TE, Puska P. Community programme for control of hypertension in North Karelia, Finland. Lancet 1980 ; ii: $900-3$.

47 Nissinen A, Tuomilehto J, Kottke TE, Puska P. Costeffectiveness of the North Karelia hypertension program effectiveness of the North Karelia hyperte

48 Dietrich AJ, O'Connor GT, Keller A, Carney PA, Levy D Whaley FS. Cancer - improving early detection an prevention-a community practice randomized trial BMF 1992; 304: 687-91.

49 Kottke TE, Battista RN, DeFriese GH, Brekke ML Attributes of successful smoking cessation intervention in medical practice. A meta-analysis of 39 controlled trials. $\mathcal{F A} M A$ 1988; 259: 2882-9.

50 Cummings SR, Rubin SM, Oster G. The cost-effectiveness of counseling smokers to quit. $7 A M A 1989 ; 261$ : 75-9.

51 Anda RF, Remington PL, Sinenko DG, Davis RM. Are physicians advising smokers to quit? The patient's physicians advising smokers to quit?
perspective. $\mathscr{f} A M A 1987 ; 257: 1916-9$.

52 Frank E, Winkleby MA, Altman DG, Rockhill B, Fortman SP. Predictors of physicians' smoking cessation advice fAMA 1991; 266: 3139-44. 